\title{
Knowledge and Utilization of Mushroom as a Food Supplement among Families in Selected Local Government Areas of Cross River State, Nigeria
}

\author{
M. A. Mgbekem ${ }^{1}$, F. Lukpata ${ }^{1}$, N. Ndukaku', M. Armon' ${ }^{1}$, \\ V. K. Uka1, G. N. Udosen ${ }^{1}$, Adrew-Bassey Pricilla ${ }^{2}$ \\ ${ }^{1}$ Department of Nursing Science, University of Calabar, Calabar, Nigeria \\ ${ }^{2}$ Department of Nursing, University of Calabar Teaching Hospital, Calabar, Nigeria \\ Email: *achimgbekem@yahoo.com
}

How to cite this paper: Mgbekem, M.A., Lukpata, F., Ndukaku, N., Armon, M., Uka, V.K., Udosen, G.N. and Pricilla, A.-B. (2019) Knowledge and Utilization of Mushroom as a Food Supplement among Families in Selected Local Government Areas of Cross River State, Nigeria. Food and Nutrition Sciences, 10, 1287-1299.

https://doi.org/10.4236/fns.2019.1011093

Received: September 3, 2019

Accepted: November 11, 2019

Published: November 14, 2019

Copyright $\odot 2019$ by author(s) and Scientific Research Publishing Inc. This work is licensed under the Creative Commons Attribution International License (CC BY 4.0).

http://creativecommons.org/licenses/by/4.0/

\begin{abstract}
The demand for health consciousness to prevent malnutrition, a high risk factor in developing countries especially in the rural areas is increasing. This study was designed to assess the level of knowledge and utilization of mushroom as a food supplement in six Local Government Areas of Cross River State, one predominantly urban and the other five mostly rural. Data were collected using a structured questionnaire from a total of 250 participants. Findings revealed that 178 (71.2\%) of respondents had good knowledge of mushrooms as food supplement $205(82 \%)$ utilized them as such, while majority of the participants 243 (93.6\%) $20.1 \%$ said it is part of the family diet if available. Chi-square analysis showed statically significant association between knowledge and utilization $\left(X^{2} \mathrm{cal}=89.62^{\mathrm{a}}, X^{2}\right.$ tab $=3.84 ; \mathrm{df}=1, \mathrm{p}<$ $0.05)$. In conclusion, we envision mushrooms as the most cost-effective source of a healthier diet tackling food insecurity, diversification and malnutrition for families in Cross River.
\end{abstract}

\section{Keywords}

Knowledge, Utilization, Mushroom, Food Supplement

\section{Background to the Study}

There is urgent demand for health consciousness to prevent malnutrition; a high risk factor in developing countries especially in the rural areas. Malnutrition is the leading cause of ill health in the developing world with micronutrient defi- 
ciencies playing a pivotal role. Supplementation with high micronutrients dense foods has proven to greatly reduce malnutrition and improve food security among individuals [1]. The role of micronutrients in health and disease is being extensively studied and they are found to be essential for cell defense, antioxidant defense mechanisms and prevention of chronic diseases [2]. Increasing awareness about the role of micronutrients in health and disease has resulted in the extensive advocate inclusion and consumption of mushrooms that compete favourably with meat, an animal protein source. Malnutrition can be prevented or reduced with high consumption of mushroom [3]. Local knowledge about the use of mushroom as food, medicinal application, recreational objects, beliefs and myths, as well as income generating activity to poor households is well documented in different parts of the world [4]. Mushrooms are fungi, distinct in nature and classified as their own kingdom-separate from plants or animals even though its taxonomy is with vegetables. They are fruiting bodies of macroscopic filamentous fungi that grow above the ground, and have been a part of the human diet, celebrated as a source of powerful nutrients and used as both food and medicine for centuries especially among Eastern cultures [5]. They are described as the "forgotten source of nutrients". Mdachi [6], Daba [7], Klupp [8] assert that mushrooms are a good source of B vitamins, riboflavin, niacin, and pantothenic acid, that helps to provide energy by breaking down proteins, fats and carbohydrates.

Mushrooms, the fruiting bodies of macroscopic filamentous fungi, are visible to the naked eye. They are like a flower or a fruit of the plant which are distinct in nature and separate from plants or animals. All mushrooms are fungi, but not all fungi are mushrooms. Mushrooms usually grow in rich organic substrates. They play a vital role in every ecosystem, and they grow in forests, gardens, lawns, meadows, pastures on any nutrient rich soil excluding clay soil and sand and come in lots of different shapes, sizes, and colors. The ones that are not toxic happen to be quite healthy, and tasty too without sodium or fat. For many years they have been used for their unique ability to add flavor in lots of different cultures' cuisines. Mushrooms are classified into food grouping systems by their use as a vegetable. Mushrooms have long been celebrated as a source of powerful nutrients and used as both food and medicine for centuries especially among Eastern cultures [9]. Mushrooms are regarded as a superfood, and one of the most health-promoting foods on the planet. [10] [11] opined that an estimated $50 \%$ of edible mushrooms are considered as functional foods, meaning that they have a potentially positive effect on health beyond basic nutrition. Consuming a varied diet is a recommended approach to achieving optimal nutritional requirements. Mushroom studies assert an association of improved nutritional status with its consumption among human especially children where there is scarcity of animal protein [12]. These studies have identified mushrooms as good sources of proteins, carbohydrates, vitamins and minerals that often exceed levels registered in most widely consumed cereal staples. They, thus have widely 
advocated for inclusion of mushrooms in human nutrition in the tropical rural areas and especially where tubers, cereals or pulses are staples and meat may be rare or too expensive for a greater portion of the population [13] [14] [15]. $\mathrm{Mu}$ shroom consumption is also associated with reduction of mild cognitive impairment in adults. Emerging evidence suggests that mushrooms may have neuroprotective properties especially ergothioneine, a compound with antioxidant and anti-inflammatory properties that delay neurodegeneration [16]. This suggests why most mushrooms studies have been in the area of their apparent cancer-fighting powers since mushrooms contain a class of proteins called lectins, which are able to bind to abnormal cells and cancer cells and label the cells for destruction by the immune system. Kozarski et al. [17] assert that mushrooms are also rich in selenium. Selenium is an essential trace element needed in small quantity for good health as it is an antioxidant enzyme that helps to prevent cells from damage as it strengthens and increased durability of bones, the teeth, hair, and nails. The primary source of selenium is animal proteins; however, due to mushroom classification as fungi that feed on animal and plant matter, they are the best source of obtaining necessary amount of selenium especially among vegetarians. Mushrooms according to [6] [7] [8] [18] and [19] are great sources of protein, fiber, B vitamins (especially niacin), vitamin C, riboflavin, pantothenic acid, calcium and copper that help to provide energy by breaking down proteins, fats and carbohydrates. The combination of these nutrients helps protect heart health. Riboflavin for instance is good for red blood cells. Niacin is good for the digestive system and for maintaining healthy skin. Pantothenic acid is good for the nervous system and helps the body make the hormones it needs. Beta glucan a form of soluble dietary fiber that is strongly linked to improving cholesterol and boosting heart health is found in button mushrooms [17]. Beta glucan helps the body regulate blood sugar thereby reducing the risk of type 2 diabetes. Copper regulates and stimulates the absorption of iron from food, and properly utilize it by getting it released from primary storage spots in the body like the liver. Potassium is one of the nutrients of mushroom that is extremely important in heart, muscle, and nerve function. Mushrooms therefore can be considered as a delicacy with high nutritional and functional value that are accepted as nutraceutical foods especially due to their organoleptic merit, medicinal properties, and economic significance [10] [20] [21].

\subsection{Types of Mushrooms}

Caglarirmak [22] asserts that there are numerous edible wild mushroom species, growing in various ecological conditions. These include: Agaricus spp. (Agaricus bisporus (button mushroom), Lentinula edodes (shiitake), Pleurotus spp. (oyster), Volvariella volvacea (straw), Auricularia auriculajudae (ear), Grifola frondosa (maitake), Ganoderma lucidum (lingzhi), Hericium erinaceus (Lion's head or pom pom), Ganoderma lucidum (lingzhi), Flammulina velutipes, Tremella fuciformis (Figures 1-5). 


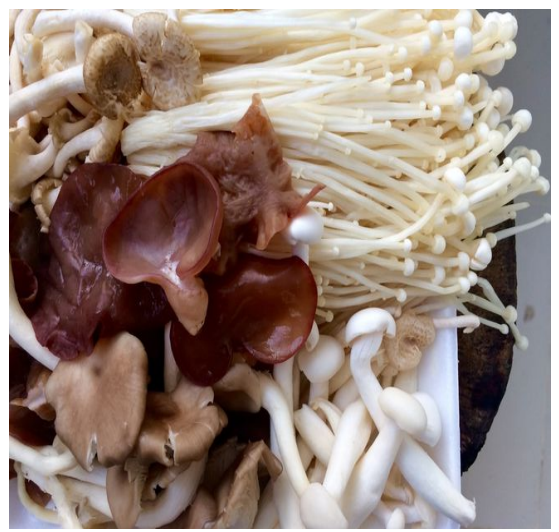

Figure 1. Collection of different mushrooms (Adapted from: Nelson, 2019; Wittaya kamkaew/Shutterstock Photo).

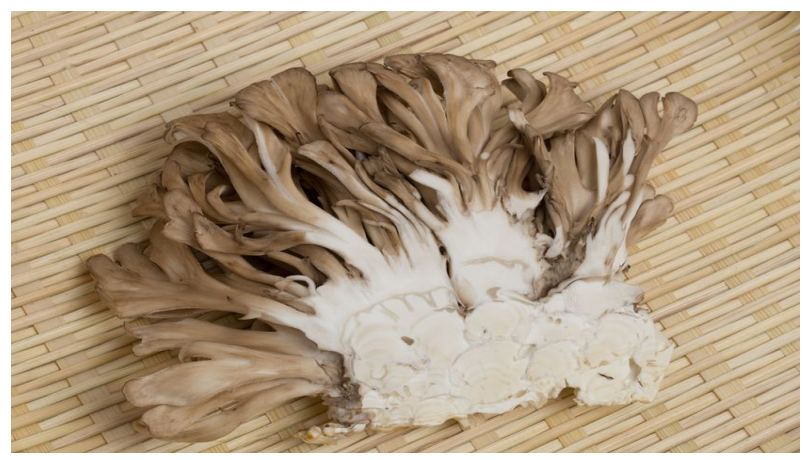

Figure 2. Maitake mushrooms (Adopted from Nelson, 2019; yoshi0511/Shutterstock Photo).

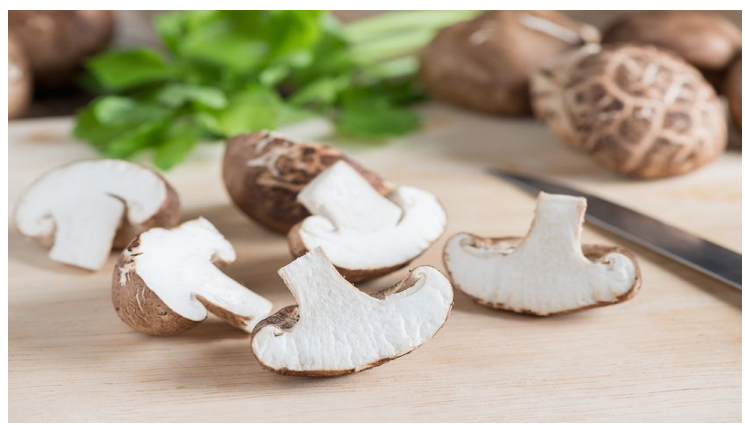

Figure 3. Shiitake mushrooms (Adapted from: Nelson, 2019; inewsfoto/Shutterstock photo).

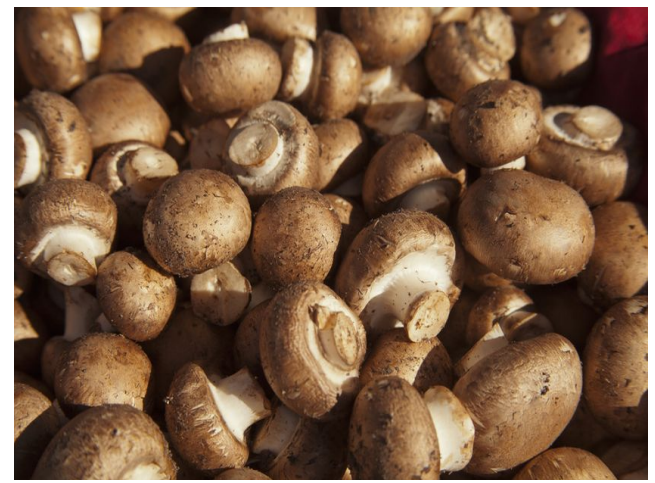

Figure 4. Cremini mushrooms photo from field notes. 


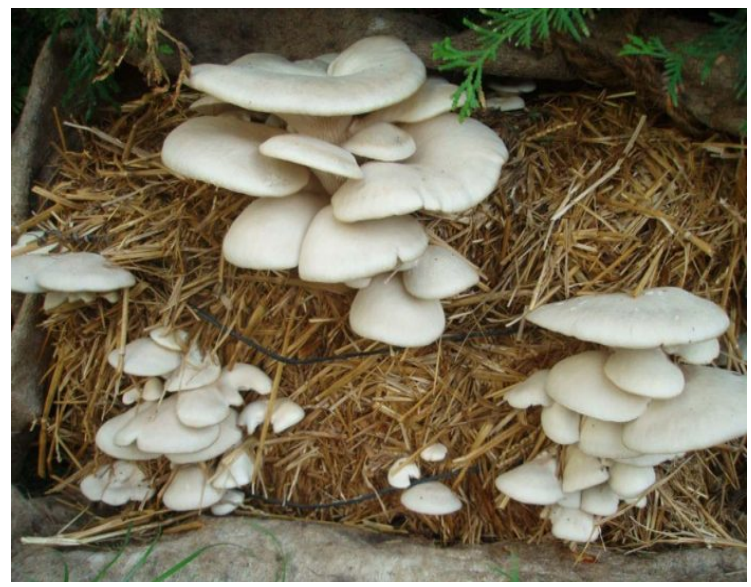

Figure 5. Mushroom home garden (From field notes).

\subsection{Nutritional Value of Mushrooms}

Nutritive value of mushrooms is well recognized [23] as they are reported to possess good flavor and favorable chemical composition with high amounts of functional proteins, low total fat level, and the high proportion of polyunsaturated fatty acids (PUFA), making them well suited for low calorie diets. Edible mushrooms provide a nutritionally significant content of vitamins $\left(B_{1}, B_{2}, B_{12}, C\right.$, $\mathrm{D}$, and $\mathrm{E}$ ) and have a low glycemic index, and high mannitol, especially beneficial for diabetics [17] [18] [24]. They also have very low sodium ( $\mathrm{Na}$ ) concentration, beneficial for hypertensive patients and a high content of potassium $(\mathrm{K})$ and phosphorus (P), important orthomolecular aspect [11]. In Asia mushrooms are used as important source of home remedies against various diseases elicited by oxidative stress [25] [26]. According to USDA Nutrition Facts [27] 100 grams of uncooked, white button mushrooms contain the following nutrients: Folate (Vitamin B9) - $16.0 \mathrm{mcg}$, Niacin (Vitamin B3) - 3.6 mg, Pantothenic Acid (Vitamin B5) $-1.5 \mathrm{mg}$, Riboflavin (Vitamin B2) $-0.4 \mathrm{mg}$, Thiamin (Vitamin B1) - $0.1 \mathrm{mg}$, Vitamin B6-0.1 mg, Copper-0.3 mg, Iron-0.5 mg Magnesium-9.0 mg, Phosphorus-86.0 mg, Potassium-318 mg, Selenium-9.3 mcg, Zinc $-0.5 \mathrm{mg}$, Fiber. Considering the increasing demand for healthy living to prevent malnutrition, a common factor in developing countries, this study was designed to: 1) determine participants' knowledge of mushrooms as food supplement that prevent malnutrition, 2) determine the usage of mushrooms in diets among participants.

\section{Methods}

This descriptive, Cross-sectional, questionnaire based study was designed to assess the level of awareness and utilization of mushroom as a food supplement in five Local Government Areas (Calabar, Ikom, Obubra, Ogoja and Obudu) of Cross River State, one predominantly urban (Calabar) and the other four mostly rural. A structured questionnaire was used for data collection from 250 subjects using stratified random sampling technique. The questionnaire was formed based 
on a review of the dietary literature on mushrooms. The questionnaire was then standardized for use in the study. Ethical approval was obtained from Cross River State Ethical Committee, Ministry of Health and Heads of various communities studied. Participants' consents were obtained and they were duly informed to feel free to withdraw from study if they wanted at any point. Some of the participants were old and could not read and write but agreed to respond to oral questions after explaining the importance of the study and their contribution to it. Data were analyzed using inferential and non-inferential statistical methods. Descriptive statistical results were reported in frequency and percentage while chi-square was used to test hypothesis.

\section{Results}

Table 1 shows the socio-demographic data of the participants. Majority of the participants were between the age range of 21 - $30(90(36 \%))$ and 31 - 40 years

Table 1. Socio-demographic data of respondents $(n=250)$.

\begin{tabular}{|c|c|c|}
\hline Variables & Frequency (n) & Percentage (\%) \\
\hline \multicolumn{3}{|l|}{ Age in Years } \\
\hline $10-20$ & 45 & 18.0 \\
\hline $21-30$ & 90 & 36.0 \\
\hline $31-40$ & 70 & 28.0 \\
\hline 41 and above & 45 & 18.0 \\
\hline Total & 250 & 100 \\
\hline \multicolumn{3}{|l|}{ Gender } \\
\hline Male & 50 & 20.0 \\
\hline Female & 200 & 80.0 \\
\hline Total & 250 & 100 \\
\hline \multicolumn{3}{|l|}{ Marital status } \\
\hline Single & 67 & 26.8 \\
\hline Married & 172 & 68.8 \\
\hline Separated & 5 & 2.0 \\
\hline Widow & 6 & 2.4 \\
\hline Total & 250 & 100 \\
\hline \multicolumn{3}{|l|}{ Educational level } \\
\hline 1) No formal education & 52 & 20.8 \\
\hline 2) Primary 6 & 63 & 25.2 \\
\hline 3) Secondary school attempted & 80 & 32.0 \\
\hline 4) Tertiary (colleges, polytechnics, university) & 55 & 22.0 \\
\hline Total & 250 & 100 \\
\hline \multicolumn{3}{|l|}{ Place of residence } \\
\hline Rural Area & 191 & 76.4 \\
\hline Urban Area & 59 & 23.6 \\
\hline Total & 250 & 100 \\
\hline
\end{tabular}


$70(28 \%)$. Most of the mushrooms gatherers 200 (80\%) as shown on the table were women, $172(68.8 \%)$ were married while 67 (26.8\%) were single, 80 (32\%) had secondary education, 55 (22\%) had tertiary education, 63 (25.2\%) were primary 6 certificate holders while $52(20.8 \%$ had no formal education. Findings show that $191(76.4 \%)$ lived in the rural areas while $59(23.6 \%)$ reside in the urban area.

Table 2 shows participants' knowledge of mushroom. The results revealed that the participants had varied views about mushrooms. Here 196 (78.4\%) of the participants said mushrooms are God's gift to man, 240 (96\%) mushrooms can influence the course of disease and the body's response to treatment, 188 $(75.2 \%)$ reported that mushrooms are some kind of vegetables very rich in minerals, $178(63.6 \%)$ asserted that there are variations among and within species of mushrooms, while 159 (63.6\%) agreed that each mushroom has its unique taste. Other responses are as shown on the table. Mean knowledge of the participants was 13.02 .

The final score for participants' knowledge on mushrooms as food supplement that prevents malnutrition was obtained by adding up participants' scores on all items in the knowledge section. The minimum score was 10 while the maximum score was 21. Thus, scores from 10 - 15 were categorized as poor knowledge while scorers between 16 and 21 were classified as good knowledge. Consequently, 178 (71.2\%) had good knowledge while 72 (28.8\%) had poor Knowledge (Figure 6).

Participants responses on utilization of mushrooms as food supplements as shown in Table 3 revealed that majority of the participants (sometimes responses) use mushrooms for various reasons (Figure 7). These answers clearly depend on mushrooms availability as clearly shown on the table.

Table 2. Knowledge of mushrooms as food supplement that prevent malnutrition $(\mathrm{n}=250)$.

\begin{tabular}{|c|c|c|c|}
\hline Statements & Yes & No & Mean $(X)$ \\
\hline Mushrooms are God's gift to man & $196(78.4 \%)$ & $54(21.6 \%)$ & \multirow{10}{*}{13.02} \\
\hline $\begin{array}{l}\text { Mushrooms are fruity structure that grow on back of dead } \\
\text { tree/dead palm trees }\end{array}$ & $162(64.8 \%)$ & $88(35.2 \%)$ & \\
\hline Mushroom is kind of vegetable that is very rich in minerals & $188(75.2 \%)$ & $62(24.8)$ & \\
\hline $\begin{array}{l}\text { Great variations occur both among and within species of } \\
\text { mushrooms }\end{array}$ & $178(71.2 \%)$ & $72(28.8 \%)$ & \\
\hline Each type of mushroom has its unique taste & $159(63.6 \%)$ & $91(36.4 \%)$ & \\
\hline Mushrooms can be used as food supplement & $171(68.4 \%)$ & $79(31.6 \%)$ & \\
\hline Mushrooms contain good sources of vitamins & $198(79.2 \%)$ & $52(20.8 \%)$ & \\
\hline Mushrooms have high protein and oxidants & $124(49.6 \%)$ & $126(50.4 \%)$ & \\
\hline $\begin{array}{l}\text { Mushrooms are low-calorie foods and they provide low } \\
\text { amounts of fat }\end{array}$ & $128(51.2 \%)$ & $122(48.8 \%)$ & \\
\hline $\begin{array}{l}\text { Mushrooms can influence the course of disease \& body's } \\
\text { response to treatment }\end{array}$ & $240(96.0 \%)$ & $10(4.0 \%)$ & \\
\hline
\end{tabular}




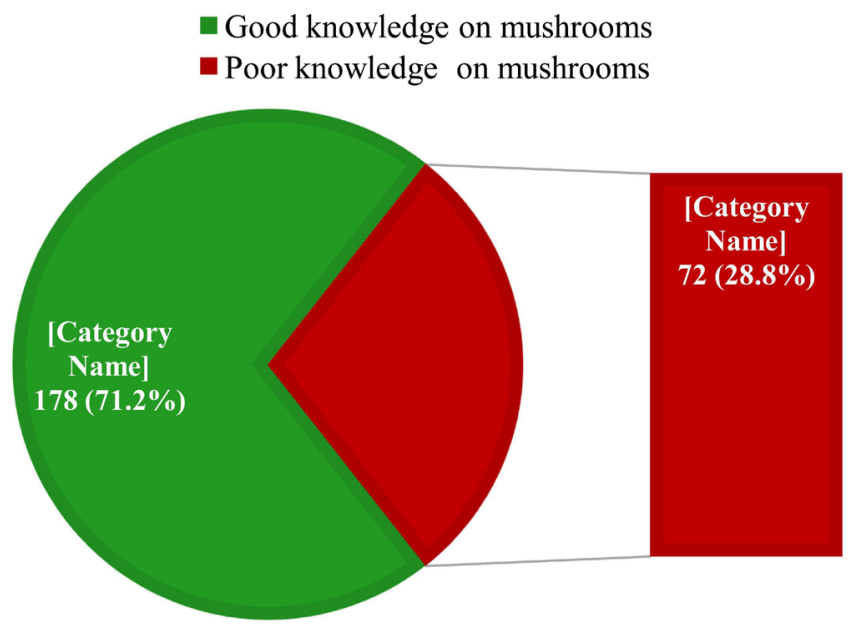

Figure 6. Summary of knowledge.

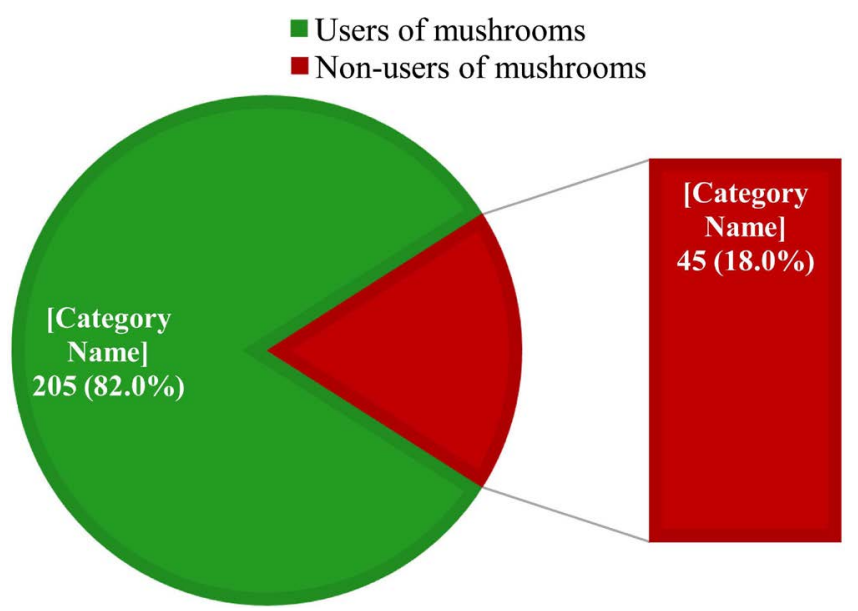

Figure 7. A pie chart showing summary of utilization of mushrooms. Scores 5 - 11 shows non-users while 12 - 18 shows users of mushrooms.

Table 3. Utilization of mushroom as food supplement $(n=250)$.

\begin{tabular}{|c|c|c|c|c|}
\hline Statements & Always & Sometimes & Rarely & Never \\
\hline I consume of mushrooms at home & $108(43.2 \%)$ & $142(56.8 \%)$ & - & - \\
\hline It constitutes part of my family menu & $190(76.0 \%)$ & $44(7.6 \%)$ & $16(6.4 \%)$ & - \\
\hline I use mushrooms in place of meat & $120(48.0 \%)$ & $77(30.8 \%)$ & $43(17.2 \%)$ & $10(4.0 \%)$ \\
\hline $\begin{array}{l}\text { I use mushrooms as home remedy against } \\
\text { various diseases }\end{array}$ & $98(39.2 \%)$ & $107(42.8 \%)$ & $39(5.6 \%)$ & $6(2.4 \%)$ \\
\hline I use mushrooms as food supplement & $72(28.8 \%)$ & $139(55.6 \%)$ & $26(10.4 \%)$ & $13(5.2 \%)$ \\
\hline $\begin{array}{l}\text { I consume mushrooms to shorten the } \\
\text { duration of a disease }\end{array}$ & $133(53.2 \%)$ & $99(39.6 \%)$ & $13(5.2 \%)$ & $5(2.0 \%)$ \\
\hline
\end{tabular}

Participant's scores for always and sometimes responses were merged to represent participants usage of mushrooms while those of rarely and never were merged to show participants responses regarding non-usage of mushrooms (Figure 8). 


\section{Hypothesis Testing}

H0: There is no statistically significant association between participant's knowledge and their utilization of mushrooms.

The result in Table 4 reveals that, the calculated $X^{2}$ value of $89.62^{\mathrm{a}}$ was greater than the critical $X^{2}$ value of 3.84 at $<0.05$ level of significance and 1 degree of freedom. Thus, the null hypothesis was rejected, implying that there was a statistically significant association between participant's knowledge and their utilization of mushrooms.

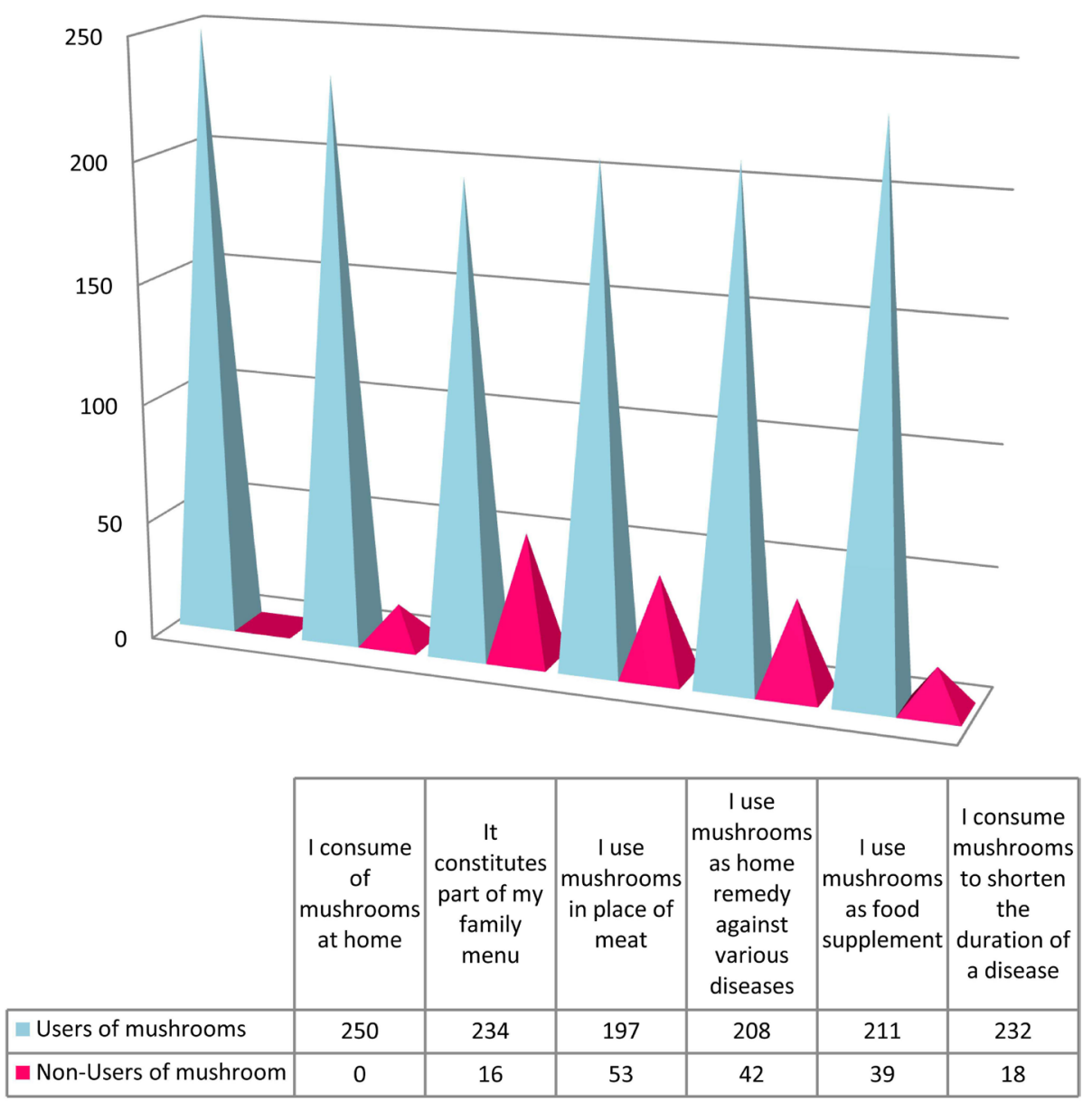

Figure 8. Showing the determined sum of scores for participant's utilization of mushrooms $\left(X^{2} \mathrm{cal}=89.62^{\mathrm{a}}, X^{2} \mathrm{tab}=3.84 ; \mathrm{df}=1, \mathrm{p}<0.05\right)$.

Table 4. Chi-Square analysis of the association between participant's knowledge and utilization of mushroom $(n=250)$.

\begin{tabular}{ccccccc}
\hline \multirow{2}{*}{ Knowledge on Mushrooms } & \multicolumn{2}{c}{ Utilisation of mushrooms } & Total & $X^{2}$ & p-level \\
\cline { 2 - 5 } & Users & Non-users & & & \\
\hline Good knowledge on mushrooms & $172(96.6 \%)$ & $6(3.4 \%)$ & $178(100.0 \%)$ & \\
Poor knowledge on mushrooms & $33(45.8 \%)$ & $39(54.2 \%)$ & $72(100 \%)$ & $89.615^{\mathrm{a}}$ & 0.000 \\
Total & $205(82.0 \%)$ & $45(18.0 \%)$ & $250(100 \%)$ & & \\
\hline
\end{tabular}

${ }^{\star}$ Significant at $(\mathrm{p}<0.05) ; \mathrm{df}=1$; critical $X^{2}=3.84$. 


\section{Discussion}

The demand for health consciousness to prevent malnutrition, reduce micronutrients deficiencies and improve household food security especially in the rural areas of the developing countries is increasing with the search for alternative foods to improve household nutrients requirement [1]. This study was conducted to assess the level of knowledge and utilization of mushroom as a food supplement in six Local Government Areas of Cross River State. Adequate food intake is essential for nutritional wellbeing and plays a role in preventing morbidity and mortality. The commonest reasons people give, for consuming certain foods are to maintain good health and ensure adequate nutrition. Humans therefore, need a wide range of nutrients to lead a healthy and active life, derived from adequate diet with essential nutrients. Amongst several essential nutrients, proteins are regarded important as body's building blocks which also stimulate several vital metabolic processes. Proteins could be sourced through several dietary ingredients like pulses, grains, milk, eggs, fish and meat. The Recommended Dietary Allowance (RDA), which is the minimum amount required to be healthy, is 0.8 grams per kilogram of body weight per day. Increasing awareness about the role of micronutrients in health and disease has resulted in the extensive advocate inclusion and consumption of mushrooms that compete favourably with meat, an animal protein source [3] [6] [7] [8] [18] [19]. Mushrooms studies have shown an association of mushrooms with good health as they are widely consumed for their consistency and great flavor making them a potential substitute for meat [3] [12] [23] an assertion supported by this study where 120 (48\%) and 77 (30.8\%) participant said they always and sometimes use mushrooms for their flavours or as meat in Table 2 and Table 3. Mushrooms are also reported to contain in abundance leucine, valine, glutamine, glutamic and aspartic acids well known amino acids. Besides proteins, edible mushrooms contain many different bioactive compounds like ergothioneine, a compound with antioxidant and anti-inflammatory properties that delays neurodegeneration [16], selenium an essential trace element and an antioxidant enzyme that helps to prevent cells from damage as it strengthens and increased durability of bones, the teeth, hair, and nails [17], vitamin C another antioxidant in combination with $\mathrm{B}$ vitamins found in them play important roles in various human health benefits.

Based on these important roles of mushrooms, the researchers assessed the participant knowledge and utilization of mushrooms. The study revealed that most of the mushrooms gatherers $200(80 \%)$ were women. This finding agrees with the observation made by other researchers who also observed that women are the principal mushroom collectors in many parts of the world, playing a central role on mushroom processing both for self-consumption and sale. This also supports the high knowledge report of the participant in the finding. It thus shows that women surely have vast knowledge on mushroom folk taxonomy, edibility, biology, as well as ecological niches as reported by [4]. Although, the 
findings revealed that most of the participants $178(71.2 \%)$ had good knowledge as they could relate mushrooms with some health benefits based on what they learnt from parents, friends and studies and could utilized the mushrooms based on the scores, 205 (82\%), of the participants, knowledge was not in-depth enough to appreciate the benefits of mushrooms maximally as a food supplement and security. Analysis of the hypothesis revealed a statistically significant association between participant's' knowledge and their utilization of mushrooms thus rejecting the null hypothesis the null hypothesis.

\section{Limitations}

This study assessed the knowledge and utilization of mushrooms from 6 LGAs in Cross River State. The results of this research are not intended to be generalizable across time or with a more geographically diverse area. This is a study limitation but the findings are an important reminder about the gaps in nutrition communication and role understanding that often exist between nutrition researchers and consumers.

\section{Conclusion}

This study has clearly demonstrated that mushrooms consumption is based on knowledge of the participants. It has therefore become apparent that information on mushrooms is made available in the research areas to improve nutritional status, reduce malnutrition and also prevent and treat the applicable non-communicable diseases. This can be achieved through health education and their importance and health implications and the use of mushrooms home gardens by households. Households can grow their mushrooms using agricultural waste either alone or in combination to make mushroom substrate to boost alternative supplement food availability [22]. Oyster mushroom for instance, is the mushroom with the simplest cultivation technology and is highly suitable for Nigerian conditions. It can be grown on wide range of substrate-rice straw, wheat straw, sorghum straw, groundnut shells, soya bean stalk, cassava or yam peels, fallen palm or other trees, sugarcane wastes etc. This home gardening method can boost food diversification and reduce malnutrition [1]. By stimulating access to and increasing availability of mushrooms as micronutrient rich foods through food diversification, the choice to eat healthier will be promoted.

\section{Conflicts of Interest}

The authors declare that they have no competing interest.

\section{References}

[1] Asemota, V.A., Etim, O.E., Okereke, S., Abubakar, G.H. and Ogbadu (2015) Mushroom Biotechnology in Nigeria-Implications for Food Security, Environment and Public Health. A Review. Journal of Advances in Biology \& Biotechnology, 2, 96-108. https://doi.org/10.9734/JABB/2015/14197

[2] Akpaja, Isikhuemhen and Okhuoya (2003) Ethnomycology and Usage of Edible 
Mushrooms among the Igbo People of Nigeria. International Journal of Medicinal Mushrooms, 5, 313-319. https://doi.org/10.1615/InterJMedicMush.v5.i3.100

[3] Adejumo, T.O. and Awosanya, O.B. (2005) Proximate and Mineral Composition of Four Edible Mushroom Species from South Western Nigerian Mushrooms: Underutilized Non-Wood Forest Resources. African Journal of Biotechnology, 4, 1084-1088.

[4] Tibuhw, D. (2013) Wild Mushroom-An Underutilized Healthy Food Resource and Income Generator: Experience from Tanzania Rural Areas. Journal of Ethnobiology and Ethnomedicine, 9, 49. http://www.ethnobiomed.com/content/9/1/49 https://doi.org/10.1186/1746-4269-9-49

[5] Wasser, S.P. (2010) Medicinal Mushroom Science: History, Current Status, Future Trends, and Unsolved Problems. International Journal of Medicinal Mushrooms, 12, 1-16. https://doi.org/10.1615/IntJMedMushr.v12.i1.10

[6] Mdachi, S.J.M., Nkunya, M.H.H., Nyigo, V.A. and Urasa, I.T. (2004) Amino Acid Composition of Some Tanzanian Wild Mushrooms. Food Chemistry, 86, 179-182. https://doi.org/10.1016/j.foodchem.2003.08.030

[7] Daba, A.S. and Ezeronye, O.U. (2003) Anti-Cancer Effect of Polysaccharides Isolated from Higher Basidiomycetes Mushrooms. African Journal of Biotechnology, 2, 272-278. https://doi.org/10.5897/AJB2003.000-1123

[8] Klupp, N.L., Chang, D., Hawke, F., Kiat, H., Cao, H., Grant, S.J. and Bensoussan, A. (2015) Ganoderma lucidum Mushroom for the Treatment of Cardiovascula Risk Factors. Cochrane Database Systematic Review, No. 2, CD007259.

https://doi.org/10.1002/14651858.CD007259.pub2

[9] Akpaja, E.O., Okhuoya, J.A. and Ehwerheferere, B.A. (2005) Ethnomycology and Indigenous Uses among the Bini Speaking People of Nigeria: A Case Study of Aihuobabekun Community near Benin City, Nigeria. International Journal of Medicinal Mushrooms, 7, 373-374. https://doi.org/10.1615/IntJMedMushr.v7.i3.270

[10] Chang, S.T. and Miles, P.G. (2008) Mushrooms Cultivation, Nutritional Value, Medicinal Effect, and Environmental Impact. 2nd Edition, CRC Press, Boca Raton.

[11] Valverde, M.E., Hernández-Pérez, T. and Paredes-López, O. (2015) Edible Mushrooms: Improving Human Health and Promoting Quality Life. International Journal of Microbiology, 2015, Article ID: 376387. https://doi.org/10.1155/2015/376387

[12] Aida, F.M.N.A., Shuhaimi, M., Yazid, M. and Maaruf, A.G. (2013) Mushroom as a Potential Source of Prebiotics: A Review. Trends in Food Science Technology, 20, 567-575. https://doi.org/10.1016/j.tifs.2009.07.007

[13] O’Neil, C.E., Nicklas, T.A. and Fulgoni, V.L. (2013) Mushroom Intake Is Associated with Better Nutrient Intake and Diet Quality: 2001-2010 National Health and Nutrition Examination Survey. Journal of Nutrition and Food Science, 3, 5.

[14] Roupas, P., Keogh, J., Noakes, M., Margetts, C. and Taylor, P. (2012) The Role of Edible Mushrooms in Health: Evaluation of the Evidence. Journal of Functional Foods, 4, 687-709. https://doi.org/10.1016/j.jff.2012.05.003

[15] Feeney, M.J., Dwyer, J., Hasler-Lewis, C., et al. (2014) Mushrooms and Health Summit Proceedings. Journal of Nutrition, 144, 1128S-1236S.

[16] Cheah, I.K., Feng, L., Tang, R.M.Y, Lim, K.H.C and Halliwell, B. (2016) Ergothioneine Levels in an Elderly Population Decrease with Age and Incidence of Cognitive Decline; a Risk Factor for Neurodegeneration? Biochemical and Biophysical Research Communications, 478, 162-167. https://doi.org/10.1016/j.bbrc.2016.07.074

[17] Barry (2019) The Association between Mushroom Consumption and Mild Cogni- 
tive Impairment: A Community-Based Cross-Sectional Study in Singapore. Journal of Alzheimer's Disease, 68, 197-203.

https://www.asianscientist.com/2019/03/health/mushroom-reduce-cognitive-declin e-ergothioneine https://doi.org/10.3233/JAD-180959

[18] Kozarski, M., Klaus, A., Vunduk, J., Zizak, Z., Niksic, M., Jakovljevic, D., Vrvic, M.M. and van Griensven, L.J.L.D. (2015) Nutraceutical Properties of the Methanolic Extract of Edible Mushroom Cantharellus cibarius (Fries): Primary Mechanisms. Food \& Function, 6, 1875-1886. https://doi.org/10.1039/C5FO00312A

[19] Mattila, P., Konko, K., Eurola, M., Pihlava, J.M., Astola, J., Vahteristo, L., Hietaniemi, V., Kumpulainen, J., Valtonen, M. and Piironen, V. (2001) Contents of Vitamins, Mineral Elements, and Some Phenolic Compounds in Cultivated $\mathrm{Mu}$ shrooms. Journal of Agricultural and Food Chemistry, 49, 2343-2348. https://doi.org/10.1021/jf001525d

[20] Chen, S.Y., Ho, K.J., Hsieh, Y.J., Wang, L.T. and Mau, J.L. (2012) Contents of Lovastatin, $\gamma$-Aminobutyric Acid and Ergothioneine in Mushroom Fruiting Bodies and Mycelia. LWT Food Science Technology, 47, 274-278.

https://doi.org/10.1016/j.lwt.2012.01.019

[21] Ergönül, A., Kalyoncu, Ergönül, Ergönül, P.G., Akata, I., Kalyoncu, F. and Ergönül, B. (2013) Fatty Acid Compositions of Six Wild Edible Mushroom Species. The Scientific World Journal, 2013, Article ID: 163964. https://doi.org/10.1155/2013/163964

[22] Loria-Kohen, V., Lourenco-Nogueira, T., Espinosa-Salinas, I., Marin, F.R., Soler-Rivas, C. and Ramirez de Molina, A. (2014) Nutritional and Functional Properties of Edible Mushrooms: A Food with Promising Health Claims. Journal of Pharmacy and Nutrition Sciences, 4, 187-198. https://doi.org/10.6000/1927-5951.2014.04.03.4

[23] Caglarirmak, N. (2011) Edible Mushrooms: An Alternative Food Item; Economical and Societal Features. Proceedings of the 7 th International Conference on $\mathrm{Mu}$ shroom Biology and Mushroom Products, Arcachon, 4-7 October 2011, 548.

[24] Chang, S.T. and Wasser, S.P. (2012) The Role of Culinary-Medicinal Mushrooms on Human Welfare with a Pyramid Model for Human Health. International Journal of Medicine Mushrooms, 14, 95-134. https://doi.org/10.1615/IntJMedMushr.v14.i2.10

[25] Finkel, T. and Holbrook, N.K. (2000) Oxidants, Oxidative Stress and the Biology of Ageing. Nature, 408, 239-247. https://doi.org/10.1038/35041687

[26] Khatua, S., Paul, S. and Acharya, K. (2013). Mushroom as the Potential Source of New Generation of Antioxidant: A Review. Journal of Pharmacological Technology, 6, 496-505.

[27] Gebhardt, S.E. and Thomas, R.G. (2002) Nutritive Value of Foods. U.S. Department of Agriculture, Agricultural Research Service, Home and Garden Bulletin 72 Nutritive Value of Foods-USDA ARS.

https://www.ars.usda.gov/ARSUserFiles/80400525/Data/hg72/hg72_2002.pdf 